\title{
Research on classroom management in Taiwan in the last ten years: A meta-analysis
}

\author{
Pai-Lu Wu ${ }^{1}$, Pai-Shih Yang ${ }^{2}$ and Ching-Hwa Tsai ${ }^{3}$ \\ ${ }^{1}$ Professor, Center for Teacher Education, Cheng-Shiu University, Taiwan \\ ${ }^{2}$ Associate Professor, Graduate Institute of Hospitality Education, National Kaohsiung University of Hospitality and Tourism, \\ Taiwan \\ ${ }^{3}$ Professor, Department of Foreign Language Instructions \& Graduate Institute of Foreign Language Education and Cultural \\ Industries, Wenzao Ursuline College of Languages, Taiwan
}

\begin{abstract}
The aim of this study is to explore researches on the topic of classroom management by Taiwanese researchers in the last 10 years from the meta-analysis perspective. The study purposes include: 1. to analyze trends in research methodology for classroom management; 2. to explore the research subjects in theses and dissertations on classroom management; 3 . to understand variables relating to the theses and dissertations on classroom management; 4. to provide suggestions for educational researchers in theses and dissertations on classroom management.

Results of this study show that in terms of research methodology: 1. There are more objective quantitative questionnaire surveys, followed by action research and case study; 2 . Transition from quantitative research to qualitative research, with a trend of balance between qualitative and quantitative. In terms of research subjects: 1 . Mostly elementary school teachers and students, followed by junior high school teachers and students; 2. Oriented toward general subjects to specific subjects for specific purposes. In terms of research variables: most background variables showed significant differences in classroom management variables; there is a trend of increasing variables relating to classroom management. In addition, research on the abstracts of classroom management and dissertations show: 1. Most theses are written for masters programs, there should be more doctoral dissertations; 2. The abstracts of theses and dissertations were insufficiently complete. Finally, the researcher provides 5 suggestions based on research findings as reference for future studies.

Index Terms - classroom management, meta-analysis approach.
\end{abstract}

\section{Introduction}

In recent years, Taiwanese universities have established many schools of education and centers for training teachers, nurturing many educational researchers in the fields of instruction or education. Educational research has continued to receive attention, with more educational research methods applied. Each year, there are more studies on education or instruction. However, among the research issues in the field of education, the issues of classroom management are closely related to education or instruction; classroom management is a necessary professional ability for teachers, and is very important in the teacher training courses as well. One of the motivations of this study is based on the emphasis placed on classroom management courses by teacher training institutions.

Bosch (2006) defined classroom management as the process of how teachers work, how classes operate, how teachers and students work together, and how instruction and learning take place. For students, classroom management refers to having partial control over class operations and understanding of how teachers and students interact. A summary of scholarly views toward classroom management shows three types. First, see classroom management as a process. For instance, Stichter, Lewis, Whittaker, Richter, Johnson, and Trussell (2009) see classroom management as a process, defining classroom management as environmental and instructional variables that promote planning, organization, expectations, and feedback in class. Second, see classroom management as objectives and outcomes. For instance, Hardin (2008) used different concerns and objectives to provide different definitions of classroom management from three perspectives, which are classroom management as a discipline, classroom management as a system, and classroom management as instruction. Third, emphasize internal traits of classroom management, for instance: Jones (1996) believed that classroom management is the main factor that affects teachers' efficacy and psychological health.

Classroom management is as important as course instruction. Karen (2006) analyzed studies about classroom management in the last 50 years in meta-analysis, finding that classroom management is a key factor that influences the learning achievements of students, even greater than students' personal abilities. Effective classroom management is a necessary condition of effective instruction, while the quality of classroom management is closely related to classroom atmosphere creation and student learning achievements. Most junior high and elementary schools in Taiwan have classes as units, with homeroom teachers in charge of all affairs of the classrooms. Most teachers also instruct classes as units, and their knowledge, capabilities, and attitudes in classroom instruction would deeply affect instructional quality and students learning effects. Thus, the second research motivation of this study is to select classroom management as the research topic.

From Taiwan National Library's National Digital Library of Theses and Dissertations in Taiwan search system, the keywords "classroom management" are used to search for theses and dissertations in the nearly 10 years between 2001 and 2010, yielding a total of 217 theses and dissertations. Among them, 43 appeared in 2008, followed by 42 in 2009, 26 in 2007, 23 in 2005 and 2010, and 17 in 2006. The number has greatly increased in the last few years, which shows that the 
issue of classroom management is a hot research topic in the field of educational research, in particular peaking in 2008 and 2009. Such rich literature on classroom management needs to be analyzed, organized, summarized, and compiled for results, in order to find a holistic understanding of the research accomplishments on classroom management in recent years. Thus, this study reviews and integrates the research topic of classroom management, which would benefit development of the classroom management issue as well as create an important reference for later engagement in researches on classroom management; this is the third motivation of this study.

Based on these research motivations, the purposes of this study include: 1 . to analyze trends in research methodology for classroom management; 2. to explore research subjects in theses and dissertations on classroom management; 3 . to understand variables relating to the theses and dissertations on classroom management; 4 . to provide suggestions for educational researchers in theses and dissertations on classroom management.

\section{Research methodology and data analysis}

\section{A. Research methodology}

Meta-analysis perspective was applied.

\section{B. Data collection}

Research papers with titles that include the words "classroom management" from the Taiwan National Library's "National Digital Library of Theses and Dissertations in Taiwan were selected. The collected abstracts of these theses and dissertations were read in order to facilitate further analysis.

\section{Data analysis}

1. In analyzing research methods for classroom management, observation, interview, verbal protocol analysis, Delphi method, and interpretive analysis are all classified as "other research methods."

2. In analyzing classroom management research subjects, literature survey, hybrid teacher groups, or websites and webpages are all classified as "other research subjects."

\section{Research limitations}

The keyword used for searching in this study is "classroom management." If theses and dissertations did not use "classroom management" as keywords, then they would not be found, even if they were studies relating to classroom management; this is a limitation of this study.

\section{Results}

\section{A. Analysis of research methodology}

Between 2001 and 2010, the theses and dissertations on classroom management are listed in Chart 1. It shows: 7 in 2001, 11 in 2002, 10 in 2003, 15 in 2004, 23 in 2005, 17 in 2006, 26 in 2007, 43 in 2008, 42 in 2009, and 23 in 2010 for a total of 217. Among the 217 theses and dissertations, 121 had questionnaire surveys at $55.8 \%, 6$ were quasi-experiment studies at $2.8 \%, 48$ had action research at $22.1 \%, 26$ had case study at $12 \%$, and 16 were in other categories at $7.4 \%$.

Chart 1 2001 2010 Research methods by type

\begin{tabular}{|c|c|c|c|c|c|c|}
\hline \multirow{2}{*}{ Year } & \multirow{2}{*}{$\begin{array}{c}\text { Total } \\
\text { number }\end{array}$} & \multicolumn{6}{|c|}{$\begin{array}{c}\text { Research methods by type } \\
\text { questionna }\end{array}$} & $\begin{array}{c}\text { quasi-experiment } \\
\text { ire surveys }\end{array}$ & $\begin{array}{c}\text { action } \\
\text { studies }\end{array}$ & $\begin{array}{c}\text { case } \\
\text { research }\end{array}$ & other \\
\hline 2010 & 23 & 15 & 0 & 4 & 4 & 0 \\
\hline 2009 & 42 & 23 & 1 & 9 & 6 & 3 \\
\hline 2008 & 43 & 19 & 1 & 11 & 8 & 4 \\
\hline 2007 & 26 & 17 & 0 & 4 & 2 & 3 \\
\hline 2006 & 17 & 11 & 2 & 1 & 2 & 1 \\
\hline 2005 & 23 & 13 & 1 & 7 & 2 & 0 \\
\hline 2004 & 15 & 7 & 1 & 7 & 0 & 0 \\
\hline 2003 & 10 & 5 & 0 & 1 & 1 & 3 \\
\hline 2002 & 11 & 5 & 0 & 4 & 0 & 2 \\
\hline 2001 & 7 & 6 & 0 & 0 & 1 & 0 \\
\hline Total & 217 & 121 & 6 & 48 & 26 & 16 \\
\hline Ratio & & $\mathbf{5 5 . 8 \%}$ & $\mathbf{2 . 8 \%}$ & $\mathbf{2 2 . 1 \%}$ & $\mathbf{1 2 . 0 \%}$ & $\mathbf{7 . 4 \%}$ \\
\hline
\end{tabular}

\section{B. Analysis of research subjects}

Classroom management research subjects between 2001 and 2010 are shown in Chart 2. Among the 217 theses and dissertations, 5 have research subjects as preschool teachers and students at $2.3 \%, 116$ have elementary school teachers and students at $53.5 \%, 55$ have junior high school teachers and students at $25.3 \%, 31$ have high and vocational school teachers and students at $14.3 \%$, and 10 have other research subjects at $4.6 \%$.

Chart 2 research subjects in theses and dissertations in 2001 2010

\begin{tabular}{|c|c|c|c|c|c|c|}
\hline \multirow[b]{2}{*}{ Year } & \multirow[b]{2}{*}{ total } & \multicolumn{5}{|c|}{ research subjects } \\
\hline & & $\begin{array}{c}\text { preschool } \\
\text { teachers and } \\
\text { students }\end{array}$ & $\begin{array}{c}\text { elementary } \\
\text { school } \\
\text { teachers and } \\
\text { students } \\
\end{array}$ & $\begin{array}{c}\text { junior high } \\
\text { school } \\
\text { teachers and } \\
\text { students }\end{array}$ & $\begin{array}{c}\text { high and } \\
\text { vocational } \\
\text { school teachers } \\
\text { and students }\end{array}$ & other \\
\hline 2010 & 23 & 0 & 12 & 6 & 5 & 0 \\
\hline 2009 & 42 & 1 & 28 & 10 & 2 & 1 \\
\hline 2008 & 43 & 1 & 30 & 9 & 3 & 0 \\
\hline 2007 & 26 & 1 & 7 & 8 & 7 & 3 \\
\hline 2006 & 17 & 0 & 9 & 4 & 3 & 1 \\
\hline 2005 & 23 & 0 & 12 & 11 & 0 & 0 \\
\hline 2004 & 15 & 1 & 3 & 3 & 5 & 3 \\
\hline 2003 & 10 & 0 & 6 & 2 & 1 & 1 \\
\hline 2002 & 11 & 1 & 7 & 2 & 1 & 0 \\
\hline 2001 & 7 & 0 & 2 & 0 & 4 & 1 \\
\hline Total & 217 & 5 & 116 & 55 & 31 & 10 \\
\hline Ratios & & $2.3 \%$ & $53.5 \%$ & $25.3 \%$ & $14.3 \%$ & $4.6 \%$ \\
\hline
\end{tabular}

C. Analysis of correlated variables in classroom management research

1. Analysis of background variables

In terms of the background variables in classroom management, personal background variables include the 12 research variables of gender, age, service years, education, marital status, job responsibilities, teaching subject, teaching 
grade, amount of time spent leading classes, the way qualification was obtained, experts and novices, symposia and cram school; school environment background variables include the 5 research variables of number of students in a class, school size, school location, school characteristics, and school history.

Further analysis shows: significant differences of personal background variables and school environment variables in terms of classroom management variables are shown in Chart 3.

Chart 3 Significant differences of personal background variables and school environment variables in terms of classroom management variables

\begin{tabular}{|c|c|c|}
\hline $\begin{array}{l}\text { classroom } \\
\text { management } \\
\text { variables }\end{array}$ & personal background variables & $\begin{array}{l}\text { school environment } \\
\text { background } \\
\text { variables }\end{array}$ \\
\hline $\begin{array}{l}\text { classroom } \\
\text { management } \\
\text { methods }\end{array}$ & gender & \\
\hline $\begin{array}{l}\text { classroom } \\
\text { management } \\
\text { strategies }\end{array}$ & $\begin{array}{l}\text { gender, age, service years, } \\
\text { marital status, job } \\
\text { responsibilities, teaching grade, } \\
\text { symposia and cram school }\end{array}$ & \\
\hline $\begin{array}{l}\text { classroom } \\
\text { management } \\
\text { efficacy }\end{array}$ & $\begin{array}{l}\text { gender, age, service years, } \\
\text { education, marital status, job } \\
\text { responsibilities, teaching subject, } \\
\text { teaching grade, experts and } \\
\text { novices, the way qualification } \\
\text { was obtained, amount of time } \\
\text { spent leading classes }\end{array}$ & $\begin{array}{l}\text { number of students } \\
\text { in a class, school } \\
\text { size, school } \\
\text { location, school } \\
\text { characteristics, } \\
\text { school history }\end{array}$ \\
\hline $\begin{array}{l}\text { classroom } \\
\text { management style }\end{array}$ & $\begin{array}{l}\text { age, job responsibilities, teaching } \\
\text { subject }\end{array}$ & \\
\hline $\begin{array}{l}\text { classroom } \\
\text { management } \\
\text { system knowledge } \\
\text { application }\end{array}$ & age, education & school location \\
\hline $\begin{array}{l}\text { classroom } \\
\text { management } \\
\text { knowledge } \\
\text { structure }\end{array}$ & experts and novices & \\
\hline $\begin{array}{l}\text { classroom } \\
\text { management } \\
\text { knowledge } \\
\text { management and } \\
\text { application }\end{array}$ & gender, service years & \\
\hline $\begin{array}{l}\text { classroom } \\
\text { management } \\
\text { learning } \\
\text { organization } \\
\text { applications }\end{array}$ & gender, job responsibilities, & school location \\
\hline
\end{tabular}

2. Analysis of classroom management and related variables

Classroom management variables include classroom management strategies, classroom management beliefs, classroom management efficacy, classroom management style and types, and classroom management knowledge. In addition, influential variables relating to classroom management include the 18 research variables of: learning motivations and adaptation, leadership behavior and styles, instructional attitudes, knowledge management, emotional management, comprehensive quality management, personality traits, classroom atmosphere, instructional beliefs, learning-based organization, self-efficacy, friendly campus, interpersonal relationships, organizational identity, marketing management, human rights attitudes, parental participation, and ethics education.

\section{Discussion and conclusions}

\section{A. Research methodology}

1. The majority involved objective and quantitative questionnaire surveys, followed by action research and case study.

Classroom management studies most commonly use questionnaire surveys as research methodology. Based on the overall and yearly categories, most still utilized questionnaire surveys (about $55.8 \%$ of the total). Thus, some research methodologies turned to action research and case study; in 2008 there was an increase in action research and case study theses. This shows that questionnaire surveys, action research, and case study are the main quantitative and qualitative research methods in classroom management. In addition, there are only 6 quasi-experiment studies.

2. Transition from quantitative to qualitative research, and a trend of balance between qualitative and quantitative research.

In 2004 and 2005, half of the studies were quantitative and the other half was qualitative. Starting in 2005, there is an increasing trend of using questionnaire surveys, while action research and case study began to increase in 2008 and 2009. In the last ten years, there have been 48 education theses using action research at $22.1 \%$ of the total; 26 theses used case study at $12.0 \%$.

\section{B. Research subjects}

1. Most are elementary school teachers and students, followed by junior high teachers and students.

2. Transitioning from general subjects to specific subjects with specific purposes.

\section{Research variables}

Most background variables showed significant difference in terms of classroom management variables; there is an increasing trend in variables relating to classroom management.

This study finds: most background variables showed significant difference in terms of classroom management variables; in addition, there is an increasing trend in studying variables of interactive relationships in classroom management (such as: learning motivation and adaptation). This may be because many master's students engaged in researching issues relating to classroom management are junior high or elementary school teachers, so when they explore the subjects of their theses, they would incorporate issues of educational reform or activities and policies of junior high and elementary schools. Thus, issues such as learning-based organizations, friendly campuses, human rights education, and ethics education would all be incorporated into relevant variables. 
D. Most theses were written by master's students, doctoral dissertations should be encouraged

This study collected 217 theses and dissertations with the keywords "classroom management"; other than one doctoral dissertation, the rest were all master's theses. This shows that most graduate students exploring classroom management were master's students. In actuality, the scope of classroom management extremely broad, and there are many topics for dissertation research. Domestic and foreign doctoral students in the education field can search for literature relating to classroom management.

\section{E. The content of thesis abstracts is insufficiently clear}

This study finds: many of the thesis abstracts on "classroom management" did not clearly describe the content, resulting in difficulties in searching and reading them. In particular, the research subjects were not clearly explained, the research methodology was not clearly defined, and the research conclusions were not specific and clear, making it difficult for readers to understand them. It was not possible to quickly understand the totality of research, and the benefit of "thesis abstracts" was lost. Incomplete research abstracts or those that are not concise cannot effectively share academic knowledge.

\section{Suggestions}

A. Clarify the definition of case study and action research to seek conformity to research purposes.

Research methodology on classroom management shows that some researchers cannot clearly define case study and action research, only labeling them as qualitative methods is lacking in clarity. In terms of research purpose and methodology, action research and case study are different. The greatest difference between them is that in action research, the researcher works in the actual context and seeks to resolve problems in actual work. Other than action cycle processes, there are also reflections of the researcher as an individual. Case study is a context with specific subjects, emphasizing contextual descriptions and behavioral analyses of cases in order to understand the uniqueness and complexity to return to the practical side of education.

B. The scope of research subjects should be expanded to special groups in the educational field..

In special education in Taiwan, there are many classes that cater to gifted students, physical education, music, fine arts, and skills purposes, as well as many classes with physically and mentally disabled students. There are even fewer studies on the classroom management of these classes. In recent years, the mainstream in special education allows students with special challenges to return to regular classes, and the impact on classroom management is worth exploring. In addition, differences or similarities between gifted and regular classroom management are also worthy of comparative analysis.

C. There should be in-depth exploration of correlations between classroom management variables and relevant variables to elevate the seriousness of academic research.

This study finds that in terms of research content, the exploration of relationships among quantitative research variables is too simplistic and cannot accentuate the relationships among mediating variables, moderating variables, independent variables, and dependent variables in the process of classroom management. Researchers should read literature on classroom management closely then design relevant variables for in-depth exploration; such research findings would have value.

D. Encourage interested doctoral students to conduct researches on classroom management to elevate research levels.

217 theses and dissertations with the keywords "classroom management" were found; other than one doctoral dissertation, the rest were all master's theses. This shows that most graduate students exploring classroom management were master's students. Thus, it is necessary to encourage interested doctoral students to research issues relating to classroom management. Doctoral students can use their own preferences and expertise in methodology to choose suitable research methods, whether quantitative or qualitative.

\section{$E$. The content of thesis abstracts should be concise and clear.}

This study suggests: empirical and quantitative research abstracts should include the research purposes, research methodology, research subjects, research tools, statistical methods, and important conclusions. Qualitative studies should at least clarify the purposes of research, case subjects, data collection methods, research findings, and reflections.

\section{References}

[1] Bosch, K. (2006). Planning classroom management: A five-step process to creating a positive learning environment. Thousand Oaks, CA: Corwin Press.

[2] Hardin, C. J. (2008). Effective classroom management: Models and strategies for today's classrooms. Upper Saddle River, NJ: Pearson Merrill Prentice Hall.

[3] Jones, V. F. (1996). Classroom management. In J. Silula (Ed.), Handbook of research on teacher education (2nd ed). New York: Macmillan.

[4] Karen, B. (2006). Planning classroom management. Thousand Oaks, CA: Corwin Press.

[5] Stichter, J. P., Lewis, T. J., Whittaker, T. A., Richter, M., Johnson, N. W., \& Trussell, R. P. (2009). Assessing Teacher Use of Opportunities to Respond and Effective Classroom Management Strategies. Journal of Positive Behavior Interventions, 11(2), 68-81. 